\title{
Sosyobilimsel Konuların Öğretimine Yönelik Ölçek Geliştirme Çalışması
}

\author{
Gizem Sakmen ${ }^{1}$, Murat Genç² \\ ${ }^{\text {I} M a t e m a t i k}$ ve Fen Bilimleri Eğitimi Anabilim Dal, Fen Bilimleri Enstitüsü, Düzce Üniversitesi, Düzce, Türkiye \\ ${ }^{2}$ Matematik ve Fen Bilimleri Eğitimi Bölümü, Eğitim Fakültesi, Düzce Üniversitesi, Düzce, Türkiye
}

Sorumlu Yazar: Gizem Sakmen, gizem.sakmen@gmail.com

Makale Türü: Araştırma Makalesi

Bilgilendirme: $\mathrm{Bu}$ makale, birinci yazarın ikinci yazarın danışmanlığında tamamladığı yüksek lisans tezine dayalı olarak oluşturulmuştur.

Kaynak Gösterimi: Sakmen, S., \& Genç, M. (2021). Sosyobilimsel konuların öğretimine yönelik ölçek geliştirme çalışması. Eğitimde Kuram ve Uygulama, 17(1), 1-19. doi: 10.17244/eku.883764

Etik Not: Araştırma ve yayın etiğine uyulmuştur. Bu araştırma için Düzce Üniversitesi Fen Bilimleri Enstitüsü Etik Kurulundan etik onay alınmıştır (Tarih: 05.11.2019, Sayı: 2019/70).

\section{Scale Development Study for Teaching Socioscientific Issues}

\author{
Gizem Sakmen ${ }^{1}$, Murat Genç² \\ ${ }^{1}$ Department of Mathematics and Science Education, Graduate School of Science, Düzce University, Düzce, Turkey \\ ${ }^{2}$ Department of Mathematics and Science Education, Faculty of Education, Düzce University, Düzce, Turkey
}

Corresponding Author: Gizem Sakmen, gizem.sakmen@gmail.com

Article Type: Research Article

Acknowledgement: This article was generated based on the first author's master thesis completed under the guidance of second author.

To Cite This Article: Sakmen, S., \& Genç, M. (2021). Sosyobilimsel konuların öğretimine yönelik ölçek geliştirme çalışması. Eğitimde Kuram ve Uygulama, 17(1), 1-19. doi: 10.17244/eku.883764

Ethical Note: Research and publication ethics were followed. For this research, the ethical approval was obtained from the Ethics Committee of Düzce University Graduate School of Science (Date: 05.11.2019, Number: 2019/70). 


\title{
Sosyobilimsel Konuların Öğretimine Yönelik Ölçek Geliştirme Çalışması
}

\author{
Gizem Sakmen ${ }^{1}$, Murat Genç² \\ 'Matematik ve Fen Bilimleri Eğitimi Anabilim Dalı, Fen Bilimleri Enstitüsü, Düzce Üniversitesi, Düzce, Türkiye \\ ${ }^{2}$ Matematik ve Fen Bilimleri Eğitimi Bölümü, Eğitim Fakültesi, Düzce Üniversitesi, Düzce, Türkiye
}

ORCID: http://orcid.org/0000-0003-3877-9294

ORCID: http://orcid.org/0000-0002-9742-1770

\begin{abstract}
$\ddot{\mathbf{O z}}$
Çalışmanın amaçlarından biri, sosyobilimsel konuların öğretimine yönelik duyuşsal eğilimleri belirleyen bir ölçek geliştirmektir. Diğer amaç ise geliştirilen ölçek ile fen bilimleri öğretmen adaylarının sosyobilimsel konuların öğretimine ilişkin duyuşsal eğilimlerini ve bu eğilimler üzerinde etkili olabilecek değişkenleri araştırmaktır. Çalışma grubunu 2019-2020 eğitim-öğretim döneminde Türkiye'de bulunan 9 farklı üniversitenin eğitim fakültelerinde öğrenim gören 126 erkek, 622 kadın olmak üzere toplam 748 fen bilimleri öğretmen adayı oluşturmaktadır. Çalışma nicel araştırma yöntemlerinden ilişkisel tarama modelinde betimsel bir çalışmadır. Taslak halinde hazırlanan ölçek öğretmen adaylarına uygulanmış, elde edilen veriler açımlayıcı ve doğrulayıcı faktör analizi ile analiz edilmiştir. Analizler sonucunda 4 boyutlu 28 maddeden oluşan bir ölçek elde edilmiştir. Ayrıca elde edilen verilerle öğretmen adaylarının sosyobilimsel konuların öğretimine yönelik duyuşsal eğilimleri ile belirlenen değişkenler arasındaki ilişki incelenmiştir. Çalışmadan elde edilen bulgulara göre adayların sosyobilimsel konuların öğretimine yönelik duyuşsal eğilimlerinde kadınlar lehine istatistiksel olarak anlamlı fark bulunmuştur. Sınıf düzeyi ve anne-baba gelir düzeyi değişkenlerine göre yalnızca öz yeterlilik alt boyutunda anlamlı farklılık bulunmuştur. Yapılan analizlere göre anne-baba eğitim düzeyi ve yerleşim yeri değişkenlerine göre herhangi bir anlamlı farklılık tespit edilmemiştir. İleride yapılacak olan çalışmalarda geliştirilen ölçek ile çeşitli eğitim düzeyinde görev yapan Biyoloji, Sınıf, Fen Bilimleri ve Sosyal Bilgiler öğretmenlerinin sosyobilimsel konuların öğretimine yönelik duyuşsal eğilimleri araştırılabilir.
\end{abstract}

\section{Makale Bilgisi \\ Anahtar kelimeler: Duyuşsal Eğilim, Fen Eğitimi, Ölçek Geliştirme, Öğretmen Adayları, Sosyobilimsel Konular}

\author{
Makale Geçmişi: \\ Geliş: 20 Şubat 2021 \\ Düzeltme: 27 Mayıs 2021 \\ Kabul: 27 Mayıs 2021
}

Makale Türü: Araştırma Makalesi

Etik Not: Araştırma ve yayın etiğine uyulmuştur. Bu araştırma için Düzce Üniversitesi Fen Bilimleri Enstitüsü Etik Kurulundan etik onay (Tarih: 05.11.2019, Sayı: 2019/70) alınmıştır. 


\title{
Scale Development Study for Teaching Socioscientific Issues
}

\begin{abstract}
One of the aims of the study is to develop a scale that determines affective tendencies towards the teaching of socioscientific issues. Another goal is to investigate the affective tendencies of science Teacher candidates related to the teaching socioscientific issues with the developed scale and the variables that might affect these trends. The participants are a total of 748 science teacher candidates, 126 men and 622 women, who study in the educational faculties of 9 different universities in Turkey during the 2019-2020 academic year. In this study quantitative-based cross-sectional survey design is used. First version of the test was administered to teacher candidates and obtained data were analyzed via an explanatory and confirmatory factor analysis. As a result of the analyses, developed scale consisted of 28 items with 4 factors. In addition, the data examined whether the relationship between the affective tendencies of teacher candidates for teaching socioscientific issues change in terms of some demographic variables. Results of this study indicated that teacher candidates' views on teaching socioscientific issues differed significantly in favor of women. Only a significant difference was found in the lower self-efficacy dimension of the scale compared to class level and parental income variables. According to the analysis, no significant differences were found among the education level of parents and in terms of their residents. The developed scale might be used in future studies to investigate the affective tendencies of science and social studies, biology, and primary school teachers related to teaching socioscientific issues.
\end{abstract}

\author{
Article Info \\ Keywords: Affective \\ Tendency, Scale Development, \\ Science Education, \\ Socioscientific Issues, Teacher \\ Candidates
}

\section{Article History:}

Received: 20 February 2021

Revised: 27 May 2021

Accepted: 27 May 2021

Article Type: Research Article 


\section{Extended Summary}

\section{Introduction}

Social issues in the subject areas of science can benefit society, but also cause many environmental problems and social problems. Shaping the perspectives of individuals in society towards these social issues from an early age is of great importance for the development of society. In the field article, researchers covered these social issues within the scope of social issues related to science, socio-scientific issues, or science-technology-society issues. Socioscientific issues can be sorted as acid rain, air pollution, organ donation, global climate change, vaccines, erosion, nuclear power plants, hydroelectric power plants, the Greenhouse Effect, space, pollution, euthanasia, cloning, etc.

One of the most important factors of socio-scientific subject-based education is the teachers who will perform the teaching. To educate individuals of the desired quality with effective teaching related to socio-scientific issues, the transfer of teaching by different technical methods, the inclusion of subjects in the science curriculum in different ways, the formation of high-level skills in students can be realized under the influence of teachers. For this reason, teachers and candidate teachers should have the necessary equipment for teaching socio-scientific issues. In studies aimed at teaching socio-scientific issues, it is also seen that interview method, semi-structured and observation forms are used in the data collection process. As a result of the study of the field, no scale was found for the teaching of socio-scientific issues. This research will help determine the affective tendencies of teacher candidates for teaching socio-scientific issues. At the same time, this study studies variables that may have an impact on these trends. It is expected that the research will contribute to future studies in the field.

One of the goals of this study is to develop a scale that determines affective tendencies towards the teaching of socioscientific issues. Another goal is to investigate the affective tendencies of science teacher candidates related to the teaching of socio-scientific issues with the developed scale and the variables that can affect these trends. For these purposes, the answers to the following research question were sought: "Do teacher candidates' affective tendencies towards teaching socioscientific issues differ according to gender, class level, mother's education level, father's education level, family residence and family income level?".

\section{Method}

This study is a descriptive study in relational scanning model, one of the quantitative research methods, in terms of its suitability to the research process and data collection process. As the basic principle in studies using quantitative methods; the data obtained are expressible and measurable numerically. The sample of the study consists of students studying in the 3rd and 4th grades of the Science Education Department at the education faculties of 9 different universities in the 2019-2020 academic year. 622 of the teacher candidates are women and 126 are men. The data obtained after the application were used in statistical analysis for the scale and analysis for variables. While analyzing the scale, the data obtained from the sample were divided into two and used in Exploratory Factor Analysis (EFA) and Confirmatory Factor Analysis (CFA).

\section{Collecting Data}

During the application, the 42-item scale, which took its final form after the expert opinion stage, was used. The study was applied to pre-service teachers at different times within 8 weeks, so as not to prevent students' lessons after the application permission letter. The participants completed to respond the scale around 15 minutes.

\section{Statistical Analysis of Data}

The data obtained from the sample were randomly divided into half and the data obtained from 374 pre-service teachers were used in exploratory factor analysis. As a result of the analysis, 4 factors with eigenvalues greater than 1 of the scale were determined. The total variance value of these 4 factors according to the scale obtained was found to be $55.18 \%$. Considering the item contents, the researcher named the 1st factor as "Pedagogical Field Competence", the 2nd factor as "Benefit and Importance", the 3rd factor as "Self-Efficacy" and the 4th factor as "Attitude".

In this study, for the confirmatory factor analysis data, the analysis results of the data of 374 pre-service teachers, excluding those used in the exploratory factor analysis, were used. According to the analysis results, the factors obtained after the confirmatory factor analysis were named in accordance with the quality of the scale. As a result of the analysis, the Affective Tendency Scale for Teaching Socioscientific Issues was finalized with 28 items in total.

\section{Discussion and Conclusion}

The developed scale was applied to prospective teachers and the variables and findings that serve the purpose were examined. It was observed that the affective tendencies of the teacher candidates towards teaching socioscientific issues differ according to the gender variable. It can be said that female teacher candidates have more positive affective tendencies about teaching socioscientific issues than men. According to the findings obtained from the study, it was 
determined that there is a significant difference in favor of the 4th grade candidates only in the "Self-efficacy" subdimension in the affective tendencies of the 3rd and 4th grades teacher candidates for teaching socioscientific issues. It can be said that the reason for this is the perception of competence given by having seen all the courses that include socioscientific issues in the last year. No significant difference was found in the affective tendencies of teacher candidates towards teaching socioscientific issues according to the education level of parents. Similarly, a significant difference was not found in the affective tendencies of the candidates towards teaching socioscientific issues according to the family location variable. Affective tendencies of the candidates towards teaching socioscientific issues differ significantly according to family income levels only in the self-efficacy sub-dimension. 


\section{Giriş}

Sosyobilimsel konular (SBK), sürekli değişim ve gelişim içerisinde olan dünyamızda karşımıza çıkmaktadır. Öğrencilerin bu konuları iyi bir şekilde kavrayabilmeleri için bu doğrultuda yetiştirilmeleri gerektiği düşünülmektedir (Yolagiden, 2017). SBK'nin farkına varan, bu konularla ilgili kendisini düşünmeye sevk eden bireylerin varlığının toplum yararına olması kaçınılmaz bir gerçektir. Buradan hareketle SBK'nin fen eğitimi kapsamındaki öğretime dâhil edilmesinin gerekçesi karar verme, sorgulama gibi becerilere sahip sorumluluk bilinci gelişmiş bireylerin topluma kazandırılması olarak bildirilmektedir (Kolsto, 2006; Sadler, 2004). Ayrıca öğrencilerin SBK hakkında yeterli bilgi düzeyine sahip olmaları aynı zamanda bu konular hakkında kendi kararlarını verebilmelerine Fen Bilimleri dersinde imkân sağlanmaktadır (Topçu, 2017).

Ülkemizde Milli Eğitim Bakanlığı (MEB), Fen Bilimleri dersi öğretim programının amacını; problem çözme becerisine sahip, sorgulayıcı, yenilenen teknolojiyi kavramada ve kullanmada başarılı, kendi başına doğru kararlar alabilen, öğrenmeyi yaşam şekli haline getirmiş fen okuryazarı bireyler yetiştirmek olarak belirlemiştir (Milli Eğitim Bakanlığı [MEB], 2006). Bu amaç doğrultusunda bireylerin, farklı düşünme biçimlerine olanak sağlayan, fen bilimleriyle ilişkili sosyobilimsel konular (SBK) hakkında bilinçli karar vermeleri gerekmektedir. SBK, bireylerin toplumu ilgilendiren bilimsel içerikli konularda bilişsel, duyuşsal ve sosyal gelişimlerine destek olan konular olmas1 nedeniyle bu konuların öğretim programlarına eklenmesinin fen okuryazarlığına katkısı olduğu ifade edilmektedir (Dawson ve Venville, 2009).

Fen bilimleri konu alanları içerisinde incelediğimiz sosyal konular, toplum açısından fayda sağlarken aynı zamanda birçok çevre sorunlarına ve toplumsal sorunlara da sebep olabilmektedir. Toplumdaki bireylerin küçük yaşlardan itibaren bu sosyal konulara karşı olan bakış açılarının şekillenmesi toplumun kalkındırılabilmesi için büyük önem taşımaktadır. Fen Bilimleri öğretim programlarında yansıtılan temel hedef (;) herkes için fen anlayışını geliştirmek ve bireyleri fen okuryazarı olarak yetiştirmektir (MEB, 2018). Fen okuryazarlığ1; bilimsel araştırma yöntemlerini kavrama, fen, teknoloji ve toplumun birbirleri ile olan etkileşimini anlama, okulda teorik olarak öğrenilen bilgileri günlük yaşamda problem çözerken, fenle ilgili toplumsal sorunların açıklamasını yaparken ve karar verirken kullanabilme, fen içerikli yazılar yazabilme, okuyabilme ve anlayabilme, bilimsel tartışmalara kendi fikir ve yorumlarını belirterek katılabilme, tarafsız, eleştirel ve yaratıcı düşünebilmek için ihtiyaç duyulan bilgi ve becerilere sahip olma şeklinde ifade edilebilir (Çepni vd., 2003). Bireyin fen okuryazarı olarak yetiştirilmesinde ülkemizde ortaya çıkmış 2013 ve 2018 öğretim programlarında yer alan Fen-Teknoloji-Toplum-Çevre (FTTÇ) ve Fen-Mühendislik-TeknolojiToplum-Çevre (FMTTÇ) öğrenme alanları bu amaç doğrultusunda önemli bir yere sahiptir. Bu bağlamda toplumla etkileşim içerisinde olan sosyal konular, fen okuryazarlığı ve fen mühendislik teknoloji toplum çevre eğitimlerinin önemli bir parçası olarak karşımıza çıkmaktadır. Alan yazınında araştırmacılar bu sosyal konuları; fenle ilgili sosyal konular, sosyobilimsel konular ya da fen-teknoloji-toplum konuları kapsamında ele almışlardır (Alaçam-Akşit, 2011). Sosyobilimsel konular; asit yağmurları, hava kirliliği, organ bağışı, küresel iklim değişikliği, aşı, erozyon, nükleer santraller, hidroelektrik santraller, sera etkisi, uzay kirliliği, ötenazi, genetik kopyalama vb. şeklinde suralanabilir. Bu konular toplumsal olarak da önem arz etmesi sebebiyle okullarda FMTTÇ öğrenme alanları içerisinde öğrencilere aktarılmaktadır.

Sosyobilimsel konu tabanlı eğitimin en önemli faktörlerinden biri de öğretimi gerçekleştirecek olan öğretmenlerdir. Çünkü SBK ile ilgili etkili bir öğretimle istenilen nitelikte bireylerin yetişmesi için öğretimin farklı teknik yöntemlerle aktarılması, konuların fen müfredatına farklı şekillerde dâhil edilmesi, öğrencilerde üst düzey becerilerin oluşumunun sağlanması öğretmenlerin etkisiyle gerçekleşebilmektedir. Bu sebeple öğretmen ve öğretmen adaylarının SBK öğretimine yönelik gerekli donanıma sahip olmaları gerekmektedir.

Genç ve Genç (2017), SBK üzerine yapmış oldukları analiz çalışmasının sonucunda Türkiye'de en az çalışılan konunun SBK'nin öğretimine yönelik olduğunu belirtmişlerdir. Bu çalışma yapılan alanyazın incelemesini de destekler niteliktedir. SBK'nin öğretimine yönelik yapılan çalışmalarda da veri toplama sürecinde görüşme yönteminden, yarı yapılandırılmış ve gözlem formlarından yararlanıldığı görülmektedir (Sıbıç, 2017; Özhan, 2018; Owens vd., 2019). Alanyazın incelemesi sonucunda SBK'nin öğretimine yönelik herhangi bir ölçeğe rastlanmamıştır. Aynı zamanda bu çalışma, öğretmen adaylarının sosyobilimsel konuların öğretimine yönelik duyuşsal eğilimlerini incelemek amacıyla bir ölçek geliştirilmesi ve bu eğilimlerin üzerinde etkili olabilecek değişkenleri araştırması sebebiyle de önemlidir. Araştırmanın ileride yapılacak olan alan çalışmalarına katkı sağlaması beklenmektedir.

\section{Araştırmanın Önemi}

Alanyazın incelendiğinde öğretmenlerin SBK'ye yönelik görüş, tutum ve bilgi düzeylerinin incelendiği yerli ve yabanc1 çalışmalar mevcuttur (Lee ve Witz, 2008; Reis ve Galvão, 2009; Özhan, 2018). Diğer yandan öğretmen adaylarıyla da SBK'ye yönelik tutum, bilgi düzeyi, öz yeterlilik algısı ve görüş gibi alanlarda çalışmalar yapılmıştır (Sürmeli ve Şahin, 
2010; Topçu, 2010; Alaçam-Akşit, 2011; Kara, 2012; Sönmez ve Kılınç, 2012). İncelemeler sonucunda SBK'nin öğretimine yönelik yapılan çalışmaların sınırlı sayıda olduğu belirlenmiştir. Ayrıca alanyazında SBK'nin öğretimine yönelik herhangi bir ölçeğe rastlanmamıştır. Bu çalışma, öğretmen adaylarının sosyobilimsel konuların öğretimine yönelik duyuşsal eğilimlerini incelemek amacıyla bir ölçek geliştirilmesi ve bu eğilimlerin üzerinde etkili olabilecek değişkenleri araştırması sebebiyle de önemlidir. Geliştirilen ölçekte ortaya çıkan alt boyutlar da çalışmanın SBK'nin öğretimine yönelik önemini vurgulamaktadır. Ders içerisinde sosyobilimsel bir konuya yer verilirken öğreticinin yeterli bilgiye, yetkinliğe, öğretim yöntem teknik vb. durumlarda kendisini yeterli görme derecesine karar vermelerini gerektiren maddeler "Öz yeterlilik" alt boyutu altında ifade edilmiştir. "Tutum" alt boyutundaki maddeler anlam bakımından herhangi bir sosyobilimsel konunun öğretimi kısmında bireyin kendi karar mekanizmasıyla durumları ne derecede yansıtmaya eğilimli olduğu ile ilgili bilgi vermektedir. Diğer yandan "Pedagojik Alan Bilgisi" ve "Fayda ve Önem" alt boyutları da öğretmen ve öğretmen adaylarının sınıf içerisinde SBK'nin öğretimine yönelik sahip oldukları alan bilgisi bakımından önemli maddeler içermektedir.

\section{Araştırmanın Amacı}

Bu çalışmanın amaçlardan biri, sosyobilimsel konuların öğretimine yönelik duyuşsal eğilimleri belirleyen bir ölçek geliştirmektir. Amaçlardan bir diğeri ise geliştirilen ölçek ile Fen Bilimleri öğretmen adaylarının sosyobilimsel konuların öğretimine ilişkin duyuşsal eğilimlerini ve bu eğilimler üzerinde etkili olabilecek değişkenleri (cinsiyet, sınıf düzeyi, anne-baba eğitim düzeyi, yerleşim yeri, gelir düzeyi ve eğitim görülen üniversite) araştırmaktır. Araştırmada öğretmen adaylarının SBK'nin öğretimine yönelik duyuşsal eğilimlerinin incelenmesi, araştırmacı tarafından geliştirilen ölçek ile gerçekleştirilmiştir. Bu amaçlar doğrultusunda: "Öğretmen adaylarının sosyobilimsel konuların öğretimine yönelik duyuşsal eğilimleri cinsiyet, sınıf düzeyi, anne eğitim düzeyi, baba eğitim düzeyi, aile yerleşim yeri ve aile gelir düzeyi değişkenlerine göre farklılık göstermekte midir?” sorularına cevap aranmıştır.

\section{Araştırmanın Modeli}

\section{Yöntem}

$\mathrm{Bu}$ çalışma, araştırma sürecine ve veri toplama işlemine uygunluğu açısından nicel araştırma yöntemlerinden ilişkisel tarama modelinde betimsel bir çalışmadır. Nicel yöntemlerin kullanıldığı çalışmalarda temel prensip; elde edilen verilerin sayısal olarak ifade edilebilirliği ve ölçülebilir olmasıdır. Tarama modeli ise geçmişte ya da hala var olan bir durumu, olduğu şekliyle betimlemeyi amaçlayan araştırma yaklaşımıdır (Karasar, 1994).

\section{Veri Toplama Araçları}

Araştırmada veri toplama aracı olarak dokümanlardan yararlanılmıştır. Çalışmanın dokümanları; okul öncesi eğitim programı (2013) ile okul öncesi eğitim etkinlik kitabıdır. Bu araştırmada doküman analizi yöntemi kullanılmıştır. Doküman incelemesinde temel amaç araştırılması hedeflenen olgu ya da olgular hakkında bilgi içeren yazılı metinlerin içeriğinin derinlemesine incelenmesidir (Yıldırım \& Şimşek, 2013). Doküman analizinde araştırmacı analize başlamadan önce bazı kategoriler oluşturur. Araştırmada oluşturulan kategoriler okuryazarlık becerileri, karakter özellikleri, yetkinlik ve STEAM becerileri olmuştur. Bu temaların altında dijital okuryazarlık, bilgi okuryazarlığı, iş birliği, yaratıcılık, problem çözme, sorumluluk alma, fen, matematik, mühendislik, tasarım gibi kodlar yer almıştır.

\section{Çalışma Grubu}

Araştırmanın örneklemi 2019-2020 eğitim öğretim yılında Düzce, Bartın, Bolu Abant İzzet Baysal, Sakarya, Marmara, Yıldız Teknik, Çanakkale Onsekiz Mart, Pamukkale ve Trakya Üniversitelerinin Eğitim Fakültelerindeki Fen Bilgisi Öğretmenliği Lisans Programı'nın 3 ve 4. sınıflarında okuyan 622 kadın, 126 erkek öğretmen adayı oluşturmaktadır. Araştırmanın verilerine ulaşmak için bu 9 üniversiteden toplam 748 kişiye araştırmacı tarafindan geliştirilen ölçek, gerekli izinler alınarak uygulanmıştır. Uygulama sonrasında elde edilen veriler ölçeğe yönelik istatistiksel analizlerde ve değişkenlere yönelik analizlerde kullanılmıştır. Ölçeğe yönelik analizler yapılırken örneklemden elde edilen veriler ikiye bölünerek Açımlayıcı Faktör Analizi (AFA) ve Doğrulayıcı Faktör Analizinde (DFA) kullanılmıştır. Değişkenlere yönelik bulgular için elde edilen verilerin tümü kullanılmıştır.

\section{Ölçek Geliştirme Süreci}

\section{Alanyazın Taraması}

Öğretmen adaylarının sosyobilimsel konuların öğretimine yönelik duyuşsal eğilimlerinin belirlenmesi amacıyla bir ölçek elde etmek için öncelikle alanyazın taraması yapılmıştır. İlk olarak öğretmen veya öğretmen adaylarını içerisine alan herhangi bir sosyobilimsel konu içeren araştırmalara bakılmıştır. Sosyobilimsel konular ile ilgili maddelerin ifade 
edilebilirliğini kolaylaştırmak amacıyla bu alanda yapılan makale ve tezler geniş kapsamda incelenmiştir. Ayrıca akademik veri tabanlarında organ bağışı, nükleer santral, aşı kullanımı vb. sosyobilimsel konu içerikli araştırmalar da incelenmiştir. Sosyobilimsel konulara yönelik Türkçe akademik kitaplar alanyazın taramasına katkı sağlamıştır. Elde edilen tüm veriler incelenerek madde yazım aşamasına geçilmiştir. Araştırma süresince sosyobilimsel konular ve öğretimine yönelik yerli ve yabancı kaynaklardan tarama sürdürülmüştür.

\section{Madde Yazımı Aşaması}

Alanyazın taramasından sonra, sosyobilimsel konuların öğretimine yönelik temel boyutlar, öğretmenlerin SBK'ye yönelik tutumları, yeterlilikleri, bilgi düzeyleri ve sosyobilimsel konuları öğretme şekilleri olarak belirlenmiştir. Bu temel alanlarla ilgili alanyazın taramasına ek olarak araştırmalar yapılmış, madde yazımı için veri sağlanmıştır. Bu alanları kapsayacak şekilde 31 maddelik pilot bir ölçek oluşturulmuştur. Oluşturulan maddelerin seçenekleri "Kesinlikle katılıyorum" ile "Kesinlikle katılmıyorum" arasında beş derece olacak şekilde yanıtlanabilmektedir.

\section{Uzman Görüșü Așaması}

Araştırmacılar tarafından hazırlanan ölçme araçlarında geçerlik önemli bir özelliktir. Ölçeğin geçerliğini sağlamanın en temel koşullarından biri de aracın kapsam geçerliliğini sağlamasıdır (Yiğittir ve Çalışkan, 2013). Hazırlanan ölçeğin de ilk olarak kapsam ve görünüş geçerliliğini sağlaması amaçlanmıştır. Bu nedenle 2 konu alan uzmanı ve 2 ölçme değerlendirme uzmanının görüşüne başvurulmuştur. Ayrıca MEB bünyesinde öğretmenlik yapan 5 fen bilimleri öğretmeninin de ölçeği incelemeleri ve yazılı olarak her madde için ayrı ayrı görüş belirtmeleri sağlanmıştır. Bu şekilde ölçekle ilgili görünüş geçerliliği uzman görüşü alınarak elde edilmiştir. Elde edilen görüşler sonucunda ölçekle ilgili gerekli düzenlemelere gidilmiştir. Madde havuzundaki bazı maddeler düzeltilip, uzmanların ve öğretmenlerin yazılı görüşleri dikkate alınarak amaca hizmet eden 11 madde daha ölçeğe eklenmiştir. İlgili düzenlemeler sonucunda ölçek 42 maddeye dönüştürülerek tekrardan daha önce görüşleri alınan alan uzmanlarının görüşüne sunulmuştur. Uzman görüşüne sunulan 42 maddelik ölçekte beşli likert tipi puanlama yapılmış, her birinde "Tamamen katılıyorum=5", "Katılıyorum=4", "Kararsızım=3", "Katılmıorum=2" ve "Tamamen katılmıorum=1" şeklinde bir puanlama oluşturulmuştur (Ek-1).

\section{Verilerin Toplanması}

Bu çalışma, 2019-2020 eğitim öğretim yılında belirlenen 9 üniversitede öğrenim gören 748 fen bilimleri öğretmen adayına uygulanmıştır. Uygulama esnasında uzman görüşü aşamasından sonra son halini alan 42 maddelik ölçek kullanılmıştır. Uygulama öncesinde Düzce Üniversitesi Fen Bilimleri Enstitüsü etik kurulundan etik izni (Tarih: 05.11.2019, Sayı: 2019/70) ve üniversitelerin eğitim fakültelerinden ölçeğin uygulanmasına ilişkin izinler alınmıştır. Çalışma, uygulanma izin yazısından sonra öğrencilerin derslerini engellemeyecek şekilde 8 hafta içinde farklı zamanlarda öğretmen adaylarına uygulanmıştır. Yanıtlama süresi 15 dakika olacak şekilde uygulama gerçekleştirilmiştir. Uygulama sonrasında öğretmen adaylarından elde edilen veriler doğrultusunda ölçeğe yönelik analizler yapılmıştır.

\section{Ölçeğe Yönelik İstatistiksel Bulgular}

\section{Bulgular}

$\mathrm{Bu}$ çalışmada geliştirilen ölçek ile yapı geçerliliğini sağlamak için elde edilen verilerle öncelikle Açımlayıcı Faktör Analizi (AFA) ardından Doğrulayıcı Faktör Analizi (DFA) yapılmıştır. AFA ve DFA bulgularına ait veriler aşağıda detaylı olarak verilmiş̧tir. Ayrıca ölçeğe yönelik yapılan güvenirlik çalışmaları da bu bölümde yer almaktadır.

\section{Açımlayıcı Faktör Analizine İlişkin Bulgular}

Çalışmada faktör analizi yapılmadan önce analizin uygulanabilirlik durumuna bakılmıştır. Bu aşama için KMO (KaiserMeyer-Olkin) değeri dikkate alınarak inceleme sağlanmıştır. KMO değeri 0 ile 1 arasında olabilmektedir ve 0,5'in üzerindeki KMO değerler faktör analizi için uygun görülmektedir. Ayrıca 0,5-0,7 aralığındaki KMO değerlerinin orta, 0,7-0,8 aralığındaki değerlerin iyi, 0,8-0,9 aralığındaki değerlerin çok iyi düzeyde ve 0,9 'un üzerindeki değerlerin de mükemmel olduğu kabul edilmektedir (Field, 2009). Bu çalışmanın KMO değeri 0,956 bulunmuştur. Bu değer, verilerin analiz için mükemmel özellik gösterdiğini belirtmektedir. Çalışmadaki Bartlett's Sphericity testi de verilerin homojenliği ve maddeler arası ilişkilerin tutarlılığını test etmektedir. Faktör analizinin uygunluğu için bu testin anlamlı $(\mathrm{p}<.05)$ olması gerekmektedir. Bu çalışmada Bartlett testi anlamlı olarak bulunmuştur $(\mathrm{p} \leq .05)$.

Ölçeğin uygunluğu tespit edildikten sonra AFA yapılmıştır. Örneklemden elde edilen veriler rastgele yarıya bölünüp 374 öğretmen adayından elde edilen veriler AFA'da kullanılmıştır. AFA sonucunda ölçeğin özdeğerlerinin 1'den büyük olan 4 faktör belirlenmiştir. Bu 4 faktörün elde edilen ölçeğe göre toplam varyans değeri \%55,18 olarak bulunmuştur. Ölçeğin Scree Plot grafiğine Şekil 1'de yer verilmiştir. 


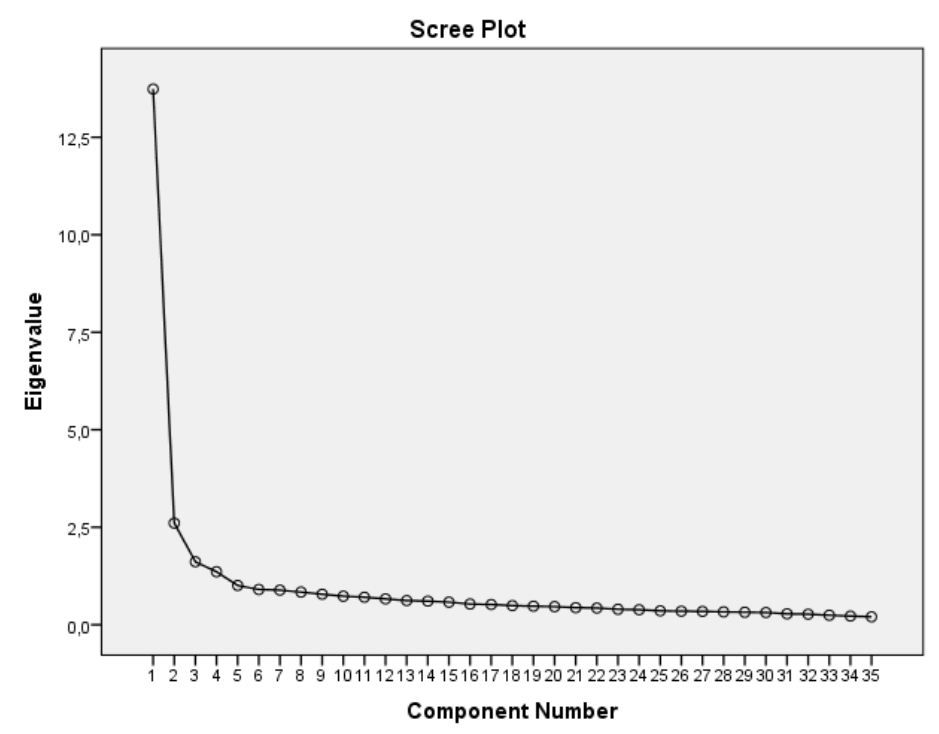

Şekil 1. Ölçeğin yapısını gösteren yamaç-birikinti grafiği (Scree Plot).

Scree Plot grafiğginde de görüldüğ̈̈ üzere değerlerin dördüncü faktörden sonra düşüş ivmesi azalmakta ve yatay olarak devam etmektedir. Grafik sonuçları Sosyobilimsel Konuların Öğretimine Yönelik Duyuşsal Eğilim Ölçeği'nin dört boyutlu bir yapıya sahip olduğunu desteklemektedir. Analizlere ait bulgulara ölçekte yer alan her bir maddenin ayrı ayrı faktör yüklerine M1 (madde 1), M2, M3,....M42 şeklinde Tablo 1'de gösterilmiştir.

Tablo 1. Madde Faktör Yükleri.

\begin{tabular}{|c|c|c|c|c|}
\hline Maddeler & 1. $\quad$ Faktör & 2. $\quad$ Faktör & 3. $\quad$ Faktör & 4. $\quad$ Faktör \\
\hline M25 & ,716 & & & \\
\hline M5 & 706 & & & \\
\hline M21 & ,705 & & & \\
\hline M22 & 699, & & & \\
\hline M18 & 678 & & & \\
\hline M7 & 675, & & & \\
\hline M4 & 665, & & & \\
\hline M9 & 659, & & & \\
\hline M8 & 658, & & & \\
\hline M14 & 657, & & & \\
\hline M19 & ,634 & & & \\
\hline M6 & 633, & & & \\
\hline M23 & 627, & & & \\
\hline M10 & 605, & & & \\
\hline M27 & 603 & & & \\
\hline M16 & 599 & & & \\
\hline M13 & ,594 & & & \\
\hline M12 & ,590 & & & \\
\hline M26 & ,578 & & & \\
\hline M37 & & ,731 & & \\
\hline M38 & & 678, & & \\
\hline M36 & & 662 & & \\
\hline M40 & & 654, & & \\
\hline M41 & & 650 & & \\
\hline M42 & & ,599 & & \\
\hline M1 & & & ,784 & \\
\hline M2 & & & ,743 & \\
\hline M39 & & & 654 & \\
\hline M33 & & & 606 & \\
\hline M3 & & &, 572 & \\
\hline M32 & & & &,- 704 \\
\hline M28 & & & & ,701 \\
\hline M15 & & & & ,686 \\
\hline M11 & & & & ,502 \\
\hline M31 & & & &,- 450 \\
\hline
\end{tabular}


Ölçekteki maddeler arasında birden fazla faktöre yüklenen maddeler bulunmuştur. Bu maddeler (M17-M20M24-M29-M30-M34-M35) sirasıyla ölçekten çıkarılmıştır. AFA sonucunda 35 maddelik 4 boyutlu bir ölçek elde edilmiştir. AFA tamamlandıktan sonra ölçek, 4 boyut altında ve 35 madde olarak güncellenmiştir. Araştırmacı tarafindan madde içerikleri dikkate alınarak 1. faktör "Pedagojik Alan Yeterliği", 2. faktör "Fayda ve Önem", 3. faktör "Öz Yeterlilik" ve 4. faktör "Tutum" olarak isimlendirilmiştir. Ölçeğin tüm faktörlerinin birbirleri ile arasındaki korelasyon katsayıları Tablo 2'de verilmiştir.

Tablo 2. Faktörler Arası Korelasyon Katsayıları.

\begin{tabular}{|c|c|c|c|c|c|}
\hline Faktörler & & Öz yeterlilik & Tutum & Fayda ve Önem & Pedagojik Alan Yeterliliği \\
\hline \multirow[t]{2}{*}{ Öz yeterlilik } & $\mathrm{r}$ & 1 & $.203^{* *}$ & $.421^{* *}$ & $.532^{* *}$ \\
\hline & $\mathrm{p}$ & & .000 & .000 & .000 \\
\hline \multirow[t]{2}{*}{ Tutum } & $\mathrm{r}$ & $.203^{* *}$ & 1 & $.221^{* *}$ & $.220^{* *}$ \\
\hline & $\mathrm{p}$ & .000 & & .000 & .000 \\
\hline \multirow[t]{2}{*}{ Fayda ve Önem } & $\mathrm{r}$ & $.421^{* *}$ & $.221^{* *}$ & 1 & $.740^{* *}$ \\
\hline & $\mathrm{p}$ & .000 & .000 & & .000 \\
\hline \multirow[t]{2}{*}{ Pedagojik Alan Yeterliliği } & $\mathrm{r}$ & $.532^{* *}$ & $.220^{* *}$ & $.740^{* *}$ & 1 \\
\hline & $\mathrm{p}$ & .000 & .000 & .000 & \\
\hline
\end{tabular}

Tablo 2 incelendiğinde tüm faktörlerin pozitif korelasyona sahip olduğu görülmektedir. Hesaplanan korelasyon katsayısında “**” işareti . 01 düzeyinde anlamlılığ 1 ifade etmektedir $(\mathrm{p}<.01)$. Ölçeğin faktörleri arasındaki korelasyon katsayıları incelendiğinde fayda ve önem faktörü ile pedagojik alan yeterliliği faktörü arasında $r=.74$ yüksek bir ilişki olduğu sonucuna ulaşılmıştır. Ayrıca öz yeterlilik faktörü ile fayda ve önem faktörü arasında $r=.42$, öz yeterlilik faktörü ile pedagojik alan yeterliliği faktörü arasında $r=.53$ orta düzeyde bir ilişki olduğu sonucuna ulaşılmıştır. Öz yeterlilik ve tutum faktörü arasında $r=.20$, tutum ile fayda ve önem faktörü arasında $r=.22$, tutum ile pedagojik alan yeterliliği faktörü arasında $r=.22$ düşük düzeyde bir ilişki olduğu sonucuna varılmıştır. Büyüköztürk vd., (2002, s.32)'e göre korelasyon katsayılarını mutlak değer olarak, 0.70 ile 1.00 arasını yüksek düzeyde, 0.70 ile 0.30 arasını orta düzeyde, 0.30 ile 0.00 arasını düşük düzeyde ilişkili olarak tanımlanmıştır.

\section{Doğrulayıcı Faktör Analizine İlişkin Bulgular}

AFA sonrası ölçeğin faktör sayısı belirlenmiş, bazı maddeler ölçekten çıkarılarak güncelleme yapılmıştır. Daha sonra ölçeğe yönelik diğer bir analiz yöntemi olan DFA yapılmıştır. DFA, çalışmadaki örneklem verilerinin kullanılmasıyla önerilen modelin uygun olup olmadığını kontrol etmek için kullanılır (Yılmaz ve Çelik, 2013). Bu çalışmada DFA verileri için AFA'da kullanılan veriler dışında kalan 374 öğretmen adayının verilerinin analiz sonuçları kullanılmıştır. Analiz sonuçlarına göre DFA sonrasında elde edilen faktörler ölçeğin niteliğine uygun olarak isimlendirilmiştir. Bazı maddelerin faktör içeriklerine uyumlu olmadıkları belirlenmiştir. Bu maddeler (M11-M12-M16-M18-M36-M38-M39) sırasıyla ölçekten çıkarılmıştır. DFA sonucunda ölçek, 4 faktör altında toplanan 28 madde ile son halini almıştır. Ölçeğin DFA bulgularına Tablo 3'te yer verilmiştir. Ayrıca tabloda, Schermelleh-Engel, Moosbrugger, H., ve Müller (2003)'e göre kabul edilen değerlendirme ölçütleri de verilmiştir.

Tablo 3. Ölçeğin DFA Bulgu ve Yorumları

\begin{tabular}{lllll}
\hline Model & $\chi^{2} / \mathbf{s d}$ & RMSEA & CFI & NNFI \\
\hline Ölçek Değerleri & 2,76 & .069 & .96 & .095 \\
Ölçütler & $\leq 3$ & $\leq 0,08$ & $\geq 0,95$ & $\geq 0,95$ \\
\hline
\end{tabular}

Bu çalışmanın Doğrulayıcı Faktör Analizinde Ki-Kare, RMSEA, CFI, NNFI, kullanılmıştır. Tablo 3 incelendiğinde Sosyobilimsel Konuların Öğretimine Yönelik Duyuşsal Eğilim Ölçeği’nin $\chi 2 / \mathrm{df}$ değeri 2,76 çıkmıştır. $\mathrm{Bu}$ değer ölçek için kabul edilebilirliği ifade etmektedir $(\chi 2 / \mathrm{df} \leq 3)$. Ayrıca tablo incelendiğinde $\mathrm{RMSEA}=0,069$, $\mathrm{CFI}=0,96$ ve NNFI $=0,095$ olduğu görülmektedir. Dolayısıyla bu sonuçlar tablodaki değerlerin kabul edilebilir olduğunu göstermektedir. DFA sonucunda ortaya çıkan verilere Şekil 2'de yer verilmiştir. 


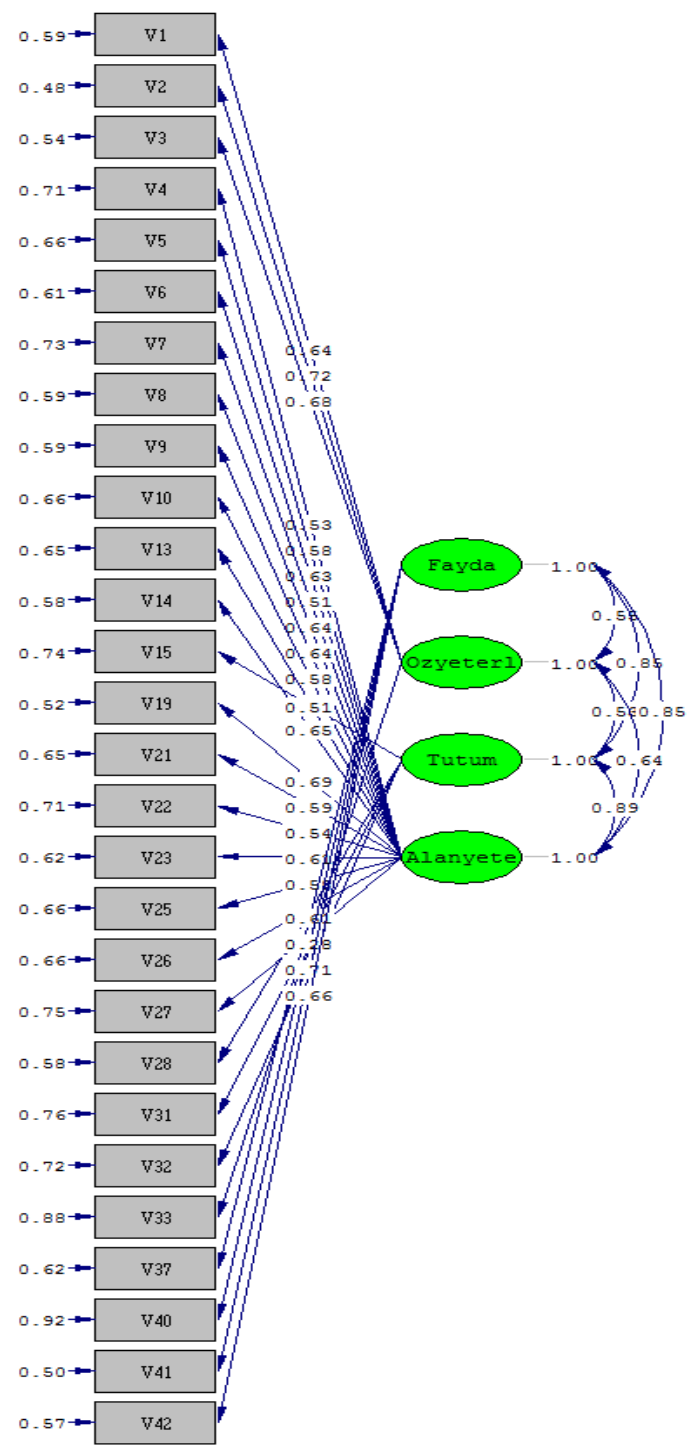

Şekil 2. Ölçeğin DFA Veri Analizi Tablo Görseli.

Şekil 2 incelendiğinde ölçekte Fayda ve Önem, Öz yeterlik, Tutum, Pedagojik Alan Yeterliliği olmak üzere toplamda 4 faktörün yer aldığı görülmektedir. Ölçekteki 24 madde olumlu ifadeler içerirken, M13, M21, M22 ve M23 sosyobilimsel konuların öğretimine yönelik olumsuz ifadeler içermesi sebebiyle ters kodlanmaktadır. "Öz yeterlik" faktörü altında bulunan maddeler, anlam açısından incelenerek bu şekilde isimlendirilmiştir. Faktör altında öğretmen veya öğretmen adaylarının sosyobilimsel konuların öğretimi ile ilgili kendi yeterliliklerini göz önünde bulundurarak karar vermelerini gerektiren maddeler bulunmaktadır. Bandura (1986) araştırmasında öz yeterlik kavramını, bireyde davranışların ortaya çıkmasında etkili olan bir nitelik ve bireyin karşılaştığ farklı durumlarda olayların üstesinden gelmesi, yine bu durumları gerçekleştirebilme yeteneğine sahip olma inancı ve yargısı olarak nitelendirmiştir.

Tutum, bireyin ele alınan herhangi bir nesneye, duruma veya hadiseye karşı olan olumlu veya olumsuz tavrıdır (İpek ve Bayraktar, 2004). Bu ölçekte de öğretmen veya öğretmen adaylarına yönelik oluşturulmuş maddelerden içerik bakımından bu tanıma benzer nitelikte olanlar "Tutum” faktörü adı altında toplanmıştır. Ölçekte bulunan bu maddelere, öğreticinin sosyobilimsel konuların öğretimiyle ilgili kendi düşünce yapısından yola çıkarak yanıt vereceği varsayılmıştır. Maddeler anlam bakımından herhangi bir sosyobilimsel konunun öğretimi kısmında bireyin kendi karar mekanizmasıyla durumları ne derecede yansıtmaya eğilimli olduğu ile ilgilidir.

Herhangi bir öğretimin gerçekleştiği ortamda temelde büyük öneme sahip olan düşünce, yapılan öğretimin öğrenciye sağladığ 1 faydadır. Bu çalışmada yapılan ölçekte de bazı maddelerin, öğretici kişi tarafindan konunun öğrenciye yönelik sağlayacağı fayda ile ilgili içeriğe sahip olup olmamasıyla ön plana çıktığı gözlenmektedir. Sosyobilimsel konuların öğrenciye muhakeme yeteneği, bilimsel düşünme alışkanlıkları, eleştirel düşünme, karar verme gibi becerileri kazandırması önemli fayda alanlarındandır. Bu nedenle araştırmacı tarafından bu özelliklerle yakından ilişkili olan maddelerin toplandığı faktör "Fayda ve Önem" olarak adlandırılmıştır.

Alan yazında Pedagojik Alan Bilgisi bir öğretmenin sahip olması gereken belirli bilgi alanları olarak tanımlanmaktadır (Shulman, 1987). Çoğu alanda öğretmenlerin pedagojik alan bilgileriyle ilgili araştırmalar yapıldığı 
gözlenmektedir. Hazırlanan ölçekte de sosyobilimsel konuların öğretiminde öğretmen veya öğretmen adaylarının öğretim sırasında kendilerinde bulunan pedagojik alan yeterliklerini sorgulamaya yöneldikleri maddeler bulunmaktadır. Bu maddelerin yer aldığı faktör araştırmacı tarafından "Pedagojik Alan Yeterlilikleri”" olarak adlandırılmıştır. Fayda ve Önem faktörü altında 4 madde, Öz yeterlik faktörü altında 4 madde, Pedagojik Alan Yeterliliği faktörü altında 16 madde ve son olarak Tutum faktörü altında 4 madde olmak üzere ölçekte toplamda 28 madde yer almaktadır.

\section{Güvenirliğe İlişkin Bulgular}

Güvenirlik analizinde kullanılan birbirinden farklı yöntemler bulunmaktadır. Cronbach Alfa katsayısı da bu yöntemlerden biridir ve ölçeğin ilişkili yapıyı tutarlı olarak ölçmesine dair bilgi vermektedir. Bu ölçekteki güvenirliğe ilişkin bulgular Tablo 4'te gösterilmiştir.

Tablo 4. Ölçek Faktörlerinin Güvenirlik Sonuçları

\begin{tabular}{lll}
\hline Faktörler & Madde Sayısı & Cronbach Alfa \\
\hline Öz yeterlilik & 4 & .760 \\
Tutum & 4 & .607 \\
Fayda ve Önem & 4 & .814 \\
Pedagojik Alan Yeterliliği & 16 & .912 \\
\hline Toplam & $\mathbf{2 8}$ & $\mathbf{9 0 9}$ \\
\hline
\end{tabular}

Tablo 4 incelendiğinde ölçeğin tümüne yönelik Cronbach Alfa değeri .909 olarak bulunmuştur. Diğer yandan öz yeterlilik boyutu için Cronbach Alpha değeri .760, tutum boyutu için Cronbach Alpha değeri .607, fayda ve önem boyutu için elde edilen Cronbach Alpha değeri .814, pedagojik alan yeterliliği boyutu için Cronbach Alpha değeri .912 olarak bulunmuştur. Alanyazında güvenirlik katsayısından elde edilen değerlerin .60- .70 arasında olması güvenirliğin kabul edilebilir düzeyde, .80 ve üzerinde olması ise yüksek düzeyde olduğunu göstermektedir (Cronbach, 1951). Geliştirilen ölçek ile toplanan verilerin güvenilir olduğu söylenebilir.

\section{Değişkenlere Yönelik Bulgular}

$\mathrm{Bu}$ kısımda öğretmen adaylarının geliştirilen ölçek maddelerine verdikleri yanıtlardan elde edilen bulgulara yer verilmiştir. Büyük örneklem boyutlarında $(\geq 500)$ test istatistiğinin ortalama olarak normal dağılım gösterdiği ifade edilmektedir (Lumley vd., 2002). Bu çalışmadaki örneklem büyüklüğü dikkate alınarak verilerin normal dağılım gösterdiği sonucuna ulaşılmıştır. Bu sebeple analizler için parametrik testler uygulanmıştır.

\section{Cinsiyet Değişkenine Yönelik Bulgular}

Fen bilimleri öğretmen adaylarının, sosyobilimsel konuların öğretimine yönelik duyuşsal eğilimlerinin cinsiyete göre değişip değişmediği araştırılmıştır. Değişkene yönelik farklılaşma olup olmadığını incelemek amaciyla t-testi bulguları Tablo 5'te gösterilmiştir.

Tablo 5. Cinsiyet Değişkenine Yönelik Bulgular.

\begin{tabular}{|c|c|c|c|c|c|c|c|}
\hline Faktör & Cinsiyet & $\mathbf{N}$ & $\overline{\mathbf{x}}$ & Ss & Sd & $\mathbf{t}$ & $\mathbf{p}$ \\
\hline \multirow[t]{2}{*}{ Öz yeterlilik } & Kadın & 622 & 14,13 & 2,44 & 746 & 1,16 & .247 \\
\hline & Erkek & 126 & 13,84 & 2,94 & & 1,02 & \\
\hline \multirow[t]{2}{*}{ Tutum } & Kadın & 622 & 13,58 & 2,84 & 746 & 4,25 & $.000 *$ \\
\hline & Erkek & 126 & 12,37 & 3,16 & & 3,96 & \\
\hline \multirow[t]{2}{*}{ Fayda ve Önem } & Kadın & 622 & 20,52 & 3,00 & 746 & 2,60 & $.009 *$ \\
\hline & Erkek & 126 & 19,75 & 3,29 & & 2,45 & \\
\hline \multirow{2}{*}{$\begin{array}{l}\text { Pedagojik Alan } \\
\text { Yeterliliği }\end{array}$} & Kadın & 622 & 73,45 & 9,22 & 746 & 3,00 & $.003 *$ \\
\hline & Erkek & 126 & 70,67 & 10,53 & & 2,75 & \\
\hline \multirow[t]{2}{*}{ Toplam } & Kadın & 622 & 121,67 & 13,87 & 746 & 3,62 & $.000 *$ \\
\hline & Erkek & 126 & 116,63 & 15,92 & & 3,30 & \\
\hline
\end{tabular}

$* \mathrm{p}<.05$

Tablo 5'te görüldüğü gibi fen bilimleri öğretmen adaylarının sosyobilimsel konuların öğretimine yönelik öz yeterlilik boyutuna göre algıları cinsiyete göre anlamlı olarak farklılaşmamaktadır ( $\mathrm{p}>.05)$. Ancak tutum alt boyutunda kadınların $(\mathrm{t}=4,25 ; \quad \overline{\mathrm{x}}=13,58)$ puanları, erkeklerin $(\mathrm{t}=3,96 ; \overline{\mathrm{x}}=12,37)$ puanlarına göre anlamlı biçimde daha yüksektir(p<.05). Aynı şekilde tabloya göre fayda ve önem $(\mathrm{t}=2,60 ; \overline{\mathrm{x}}=20,52)$, pedagojik alan yeterliliği $(\mathrm{t}=3,00$; $\overline{\mathrm{x}}=73,45)$ boyutlarında da kadınların lehine istatistiksel olarak anlamlı bir fark olduğu görülmektedir $(\mathrm{p}<.05)$. Benzer şekilde ölçeğin toplam puanlarına bakıldığında kadınların $(\mathrm{t}=3,62 ; \overline{\mathrm{x}}=121,67)$ puanlarında, erkeklerin $(\mathrm{t}=3.30$; $\overline{\mathrm{x}}=116,63)$ puanlarına göre istatistiksel olarak anlamlı bir fark bulunmaktadır $(\mathrm{p}<.05)$. 


\section{Sınıf Düzeyi Değişkenine Yönelik Bulgular}

Fen bilimleri öğretmen adaylarının, sosyobilimsel konuların öğretimine yönelik duyuşsal eğilimlerinin sınıf düzeyine göre değişip değişmediği araştırılmıştır. Değişkene yönelik farklılaşma olup olmadığını incelemek amacıyla t-testi bulguları Tablo 6'da gösterilmiştir.

Tablo 6. Sınıf Düzeyi Değişkenine Yönelik Bulgular.

\begin{tabular}{|c|c|c|c|c|c|c|c|c|}
\hline Faktör & & Sinıf & $\mathbf{N}$ & $\overline{\mathbf{x}}$ & Ss & Sd & $\mathbf{t}$ & p \\
\hline \multirow{2}{*}{\multicolumn{2}{|c|}{ Öz yeterlilik }} & 3 & 386 & 13,69 & 2,39 & 746 & $-4,35$ & $.000 *$ \\
\hline & & 4 & 362 & 14,49 & 2,60 & & $-4,34$ & \\
\hline \multirow{2}{*}{\multicolumn{2}{|c|}{ Tutum }} & 3 & 386 & 13,55 & 2,83 & 746 & 1,69 & .092 \\
\hline & & 4 & 362 & 13,19 & 3,02 & & 1,69 & \\
\hline \multirow[t]{2}{*}{ Fayda ve Önem } & & 3 & 386 & 20,52 & 3,08 & 746 & 1,15 & .249 \\
\hline & & 4 & 362 & 20,26 & 3,04 & & 1,15 & \\
\hline \multirow{2}{*}{$\begin{array}{l}\text { Pedagojik } \\
\text { Yeterliliği }\end{array}$} & Alan & 3 & 386 & 73,12 & 9,53 & 746 & .41 & .682 \\
\hline & & 4 & 362 & 72,83 & 9,48 & & .41 & \\
\hline \multirow{2}{*}{\multicolumn{2}{|c|}{ Toplam }} & 3 & 386 & 120,88 & 13,99 & 746 & .11 & .916 \\
\hline & & 4 & 362 & 120,77 & 14,74 & & .11 & \\
\hline
\end{tabular}

${ }^{*} \mathrm{p}<.05$

Testten elde edilen sonuçlara göre 4. sınıfta $(\bar{x}=14,49)$ öğrenim gören öğretmen adaylarının, 3. Sınıfta $(\bar{x}=13,69)$ öğrenim görenlere kıyasla öz yeterlilik boyutundaki puanlarında anlamlı bir fark görülmektedir $(\mathrm{p}<.05)$. Fakat ölçeğe göre oluşturulan tutum, fayda ve önem, pedagojik alan yeterliliği boyutlarında sınıf düzeylerine göre anlamlı bir fark bulunmamaktadır ( $>$ >05). Ayrıca toplam değerlere bakıldığında da tüm katılımcılar içerisinde sınıf düzeyine göre anlamlı bir fark bulunmamaktadır (p>.05).

\section{Anne Ĕ̈itim Düzeyi Değişkenine Yönelik Bulgular}

Katılımcıların sosyobilimsel konuların öğretimine yönelik duyuşsal eğilimlerinin anne eğitim düzeyine (ilkokul, ortaokul, lise, lisans, lisansüstü, diğer) göre değişiklik gösterip göstermediği araştırılmıştır. Değişkene yönelik farklılaşma olup olmadığını incelemek amacıyla ANOVA test bulguları Tablo 7'de gösterilmiştir.

Tablo 7. Anne Eğitim Düzeyi Değişkenine Yönelik Bulgular.

\begin{tabular}{|c|c|c|c|c|c|c|}
\hline Faktör & Varyans & Kareler Toplamı & df & $\begin{array}{l}\text { Kareler } \\
\text { Ortalaması } \\
\end{array}$ & $\mathbf{F}$ & $\mathbf{p}$ \\
\hline Öz yeterlilik & $\begin{array}{l}\text { Gruplar arası } \\
\text { Grup içi } \\
\text { Toplam }\end{array}$ & $\begin{array}{l}18,753 \\
4751,594 \\
4770,346 \\
\end{array}$ & $\begin{array}{l}4 \\
743 \\
747 \\
\end{array}$ & $\begin{array}{l}4,688 \\
6,395\end{array}$ & ,733 & .570 \\
\hline Tutum & $\begin{array}{l}\text { Gruplar arası } \\
\text { Grup içi } \\
\text { Toplam }\end{array}$ & $\begin{array}{l}43,170 \\
6376,017 \\
6419,187 \\
\end{array}$ & $\begin{array}{l}4 \\
743 \\
747 \\
\end{array}$ & $\begin{array}{l}10,792 \\
8,581\end{array}$ & 1,258 & .258 \\
\hline Fayda ve Önem & $\begin{array}{l}\text { Gruplar arası } \\
\text { Grup içi } \\
\text { Toplam } \\
\end{array}$ & $\begin{array}{l}63,483 \\
6954,960 \\
7018,444 \\
\end{array}$ & $\begin{array}{l}4 \\
743 \\
747 \\
\end{array}$ & $\begin{array}{l}15,871 \\
9,361\end{array}$ & 1,695 & .149 \\
\hline $\begin{array}{ll}\text { Pedagojik } & \text { Alan } \\
\text { Yeterliliği } & \end{array}$ & $\begin{array}{l}\text { Gruplar arası } \\
\text { Grup içi } \\
\text { Toplam } \\
\end{array}$ & $\begin{array}{l}478,201 \\
66929,457 \\
67407,658 \\
\end{array}$ & $\begin{array}{l}4 \\
743 \\
747 \\
\end{array}$ & $\begin{array}{l}119,550 \\
90,080\end{array}$ & 1,327 & .258 \\
\hline Toplam & $\begin{array}{l}\text { Gruplar arası } \\
\text { Grup içi } \\
\text { Toplam } \\
\end{array}$ & $\begin{array}{l}1145,562 \\
152678,495 \\
153824,057 \\
\end{array}$ & $\begin{array}{l}4 \\
743 \\
747 \\
\end{array}$ & $\begin{array}{l}286,391 \\
205,489\end{array}$ & 1,394 & .234 \\
\hline
\end{tabular}

Tablo 7'de görüldüğü gibi öğretmen adaylarının öz yeterlilik, tutum, fayda ve önem, pedagojik alan yeterliliği alt boyutlarındaki puanları anne eğitim düzeyine göre anlamlı olarak farklılaşmamaktadır ( $p>.05)$.

\section{Baba Eğitim Düzeyi Değişkenine Yönelik Bulgular}

Katılımcıların sosyobilimsel konuların öğretimine yönelik duyuşsal eğilimlerinin baba eğitim düzeyine (ilkokul, ortaokul, lise, lisans, lisansüstü, diğer) göre değişiklik gösterip göstermediği araştırılmıştır. Değişkene yönelik farklılaşma olup olmadığını incelemek amacıyla ANOVA test bulguları Tablo 8'de gösterilmiştir. 
Tablo 8. Baba Eğitim Düzeyi Değişkenine Yönelik Bulgular.

\begin{tabular}{|c|c|c|c|c|c|c|}
\hline Faktör & Varyans & $\begin{array}{l}\text { Kareler } \\
\text { Toplamı } \\
\end{array}$ & df & $\begin{array}{l}\text { Kareler } \\
\text { Ortalaması } \\
\end{array}$ & $\mathbf{F}$ & $\mathbf{p}$ \\
\hline Öz yeterlilik & $\begin{array}{l}\text { Gruplar aras1 } \\
\text { Grup içi } \\
\text { Toplam }\end{array}$ & $\begin{array}{l}36,262 \\
4734,084 \\
4770,346\end{array}$ & $\begin{array}{l}4 \\
743 \\
747 \\
\end{array}$ & $\begin{array}{l}9,066 \\
6,372\end{array}$ & 1.423 & .225 \\
\hline Tutum & $\begin{array}{l}\text { Gruplar arası } \\
\text { Grup içi } \\
\text { Toplam } \\
\end{array}$ & $\begin{array}{l}34,215 \\
6384,972 \\
6419,187 \\
\end{array}$ & $\begin{array}{l}4 \\
743 \\
747 \\
\end{array}$ & $\begin{array}{l}8,554 \\
8,594\end{array}$ & ,995 & .409 \\
\hline Fayda ve Önem & $\begin{array}{l}\text { Gruplar arası } \\
\text { Grup içi } \\
\text { Toplam } \\
\end{array}$ & $\begin{array}{l}14,115 \\
7004,329 \\
7018,444 \\
\end{array}$ & $\begin{array}{l}4 \\
743 \\
747 \\
\end{array}$ & $\begin{array}{l}3,529 \\
9,427\end{array}$ & ,374 & .827 \\
\hline $\begin{array}{l}\text { Pedagojik Alan } \\
\text { Yeterliliği }\end{array}$ & $\begin{array}{l}\text { Gruplar arası } \\
\text { Grup içi } \\
\text { Toplam }\end{array}$ & $\begin{array}{l}537,353 \\
66870,305 \\
67407,658 \\
\end{array}$ & $\begin{array}{l}4 \\
743 \\
747 \\
\end{array}$ & $\begin{array}{l}134,338 \\
90,000\end{array}$ & 1,493 & .203 \\
\hline Toplam & $\begin{array}{l}\text { Gruplar arası } \\
\text { Grup içi } \\
\text { Toplam }\end{array}$ & $\begin{array}{l}1198,436 \\
152625,621 \\
153824,057\end{array}$ & $\begin{array}{l}4 \\
743 \\
747 \\
\end{array}$ & $\begin{array}{l}299,609 \\
205,418\end{array}$ & 1,459 & .213 \\
\hline
\end{tabular}

Tablo 8 incelendiğinde fen bilimleri öğretmen adaylarının sosyobilimsel konuların öğretimi ölçeğine verdikleri yanıtlara göre öz yeterlilik, tutum, fayda ve önem, pedagojik alan yeterliliği boyutlarındaki puanları baba eğitim düzeyine göre anlamlı olarak farklılaşmamaktadır ( $>$ >.05).

\section{Aile Yerleșim Yeri Değișkenine Yönelik Bulgular}

Katılımcıların sosyobilimsel konuların öğretimine yönelik duyuşsal eğilimlerinin anne-baba yerleşim yeri değişkenine (büyükşehir, il merkezi, ilçe, köy) göre farklılık gösterip göstermediği araştırılmıştır. Değişkene yönelik farklılaşma olup olmadığını incelemek amacıyla ANOVA test bulguları Tablo 9' da gösterilmiştir.

Tablo 9. Anne-Baba Yerleşim Yeri Değişkenine Yönelik Bulgular.

\begin{tabular}{|c|c|c|c|c|c|c|}
\hline Faktör & Varyans & $\begin{array}{l}\text { Kareler } \\
\text { Toplamı }\end{array}$ & df & $\begin{array}{l}\text { Kareler } \\
\text { Ortalaması }\end{array}$ & $\mathbf{F}$ & $\mathbf{p}$ \\
\hline \multirow[t]{3}{*}{ Öz yeterlilik } & Gruplar aras1 & 38,950 & 4 & 9,737 & 1,529 & .192 \\
\hline & Grup içi & 4731,396 & 743 & 6,368 & & \\
\hline & Toplam & 4770,346 & 747 & & & \\
\hline \multirow[t]{3}{*}{ Tutum } & Gruplar arası & 39,299 & 4 & 9,825 & 1,144 & .334 \\
\hline & Grup içi & 6379,888 & 743 & 8,587 & & \\
\hline & Toplam & 6419,187 & 747 & & & \\
\hline \multirow[t]{3}{*}{ Fayda ve Önem } & Gruplar arası & 68,555 & 4 & 17,139 & 1,832 & .121 \\
\hline & Grup içi & 6949,889 & 743 & 9,354 & & \\
\hline & Toplam & 7018,444 & 747 & & & \\
\hline Pedagojik Alan & Gruplar arası & 378,899 & 4 & 94,725 & 1,050 & .380 \\
\hline \multirow[t]{2}{*}{ Yeterliliği } & Grup içi & 67028,759 & 743 & 90,214 & & \\
\hline & Toplam & 67407,658 & 747 & & & \\
\hline \multirow[t]{3}{*}{ Toplam } & Gruplar arası & 1534,580 & 4 & 383,645 & 1,872 & .114 \\
\hline & Grup içi & 152289,477 & 743 & 204,966 & & \\
\hline & Toplam & 153824,057 & 747 & & & \\
\hline
\end{tabular}

$* \mathrm{p}<.05$

Tablo 9'a göre katılımcıların ölçeğe yönelik öz yeterlilik, tutum, fayda ve önem, pedagojik alan yeterliliği alt boyutlarındaki puanları aile yerleşim yerine göre anlamlı olarak farklılaşmamaktadır ( $\mathrm{p}>.05)$.

\section{Aile Gelir Düzeyi Değişkenine Yönelik Bulgular}

Katılımcıların sosyobilimsel konuların öğretimine yönelik duyuşsal eğilimlerinin anne-baba gelir düzeyine (0-750€, 750-1500€, 1500-2250€, 2250-3000€, 3000€ ve üzeri) göre değişiklik gösterip göstermediği araştırılmıştır. Değişkene yönelik farklılaşma olup olmadığını incelemek amacıyla ANOVA test bulguları Tablo 10'da gösterilmiştir. 
Tablo 10. Anne-Baba Gelir Düzeyi Değişkenine Yönelik Bulgular.

\begin{tabular}{|c|c|c|c|c|c|c|c|}
\hline Faktör & & Varyans & Kareler Toplamı & df & Kareler Ortalaması & $\mathbf{F}$ & $\mathbf{P}$ \\
\hline \multirow{3}{*}{\multicolumn{2}{|c|}{ Öz yeterlilik }} & Gruplar arası & 90,477 & 5 & 18,095 & 2,875 & $.014 *$ \\
\hline & & Grup içi & 4663,210 & 741 & 6,293 & & \\
\hline & & Toplam & 4753,687 & 746 & & & \\
\hline \multirow{3}{*}{\multicolumn{2}{|c|}{ Tutum }} & Gruplar arası & 61,680 & 5 & 12,336 & 1,438 & .208 \\
\hline & & Grup içi & 6357,116 & 741 & 8,579 & & \\
\hline & & Toplam & 6418,795 & 746 & & & \\
\hline \multirow{3}{*}{\multicolumn{2}{|c|}{ Fayda ve Önem }} & Gruplar aras1 & 64,436 & 5 & 12,887 & 1,373 & .232 \\
\hline & & Grup içi & 6953,639 & 741 & 9,384 & & \\
\hline & & Toplam & 7018,075 & 746 & & & \\
\hline Pedagojik & Alan & Gruplar aras1 & 614,247 & 5 & 122,849 & 1,365 & .236 \\
\hline \multirow[t]{2}{*}{ Yeterliliği } & & Grup içi & 66711,916 & 741 & 90,030 & & \\
\hline & & Toplam & 67326,163 & 746 & & & \\
\hline \multirow{3}{*}{\multicolumn{2}{|c|}{ Toplam }} & Gruplar aras1 & 1773,337 & 5 & 354,667 & 1,729 & .126 \\
\hline & & Grup içi & 152012,538 & 741 & 205,145 & & \\
\hline & & Toplam & 153785,874 & 746 & & & \\
\hline
\end{tabular}

${ }^{*} \mathrm{p}<.05$

Tablo 10'a göre katılımcıların ölçeğe yönelik öz yeterlilik alt boyutundan elde ettikleri puanlar ile aile gelir düzeyi değişkeni arasında anlamlı fark bulunmaktadır $(\mathrm{F}=2,857 ; \mathrm{p}<.05)$. Elde edilen verilere göre anlamlı farklılık, öz yeterlilik alt boyutunda gelirleri 3000 ve üzeri olan anne-babaya sahip öğretmen adaylarının lehinedir. Diğer yandan Tutum, Pedagojik Alan Yeterliliği, Fayda ve Önem alt boyutlarındaki puanlar aile gelir düzeyine göre anlamlı olarak farklılaşmamaktadır ( $\mathrm{p}>.05)$.

\section{Sonuç, Tartışma ve Öneriler}

Alan yazında SBK'ye yönelik duyuşsal eğilimleri içeren herhangi bir çalışma olmadığı için bulguların yorumlanmasında görüş, tutum vb. çalışmaların sonuçları ile karşılaştırma yapılmıştır. Ayrıca SBK'nin öğretimine yönelik daha önce geliştirilen herhangi bir ölçeğe rastlanılmadığı için bu çalışmadaki ölçek geliştirmeye yönelik bulgular kendi içinde değerlendirilmiştir. Ölçeğe yönelik güvenirlik analizinde Cronbach Alfa değerlerine bakılmış ve elde edilen bulgulara göre ölçeğin güvenilir olduğu sonucuna ulaşılmıştır. Diğer yandan ölçeğe yönelik ilk olarak kapsam ve görünüş geçerliliklerine bakılmıştır. Ölçeğe yönelik yapı geçerliliğini sağlamak için ise istatistiksel bulgulara bakılmıştır. Yapılan analizler sonucunda ölçeğin geçerli olduğu sonucuna varılmıştır.

Öğretmen adaylarının sosyobilimsel konuların öğretimine yönelik duyuşsal eğilimlerinin cinsiyet değişkenine göre farklılık gösterdiği görülmüştür. Kadın öğretmen adaylarının erkeklere göre sosyobilimsel konuların öğretimiyle ilgili duyuşsal eğilimlerinin daha olumlu yönde olduğu söylenebilir. Kadın öğretmen adaylarının duyuşsal eğilimlerinde "Tutum", "Pedagojik Alan Yeterliliği", "Fayda ve Önem" boyutlarında erkeklere göre anlamlı farklılık oluşmasına rağmen "Öz yeterlilik" boyutunda herhangi bir farklılığa rastlanmamıştır. Alanyazında Qin ve Brown (2007) sosyobilimsel bir konu olan genetiği değiştirilmiş ürünlere yönelik tutumları inceleyen araştırma yapmış, cinsiyet değişkenine göre bakıldığında kadın ve erkeklerin aralarında anlamlı bir fark bulmuş ve bu farklılığın kadınlar lehine olduğunu ortaya koymuşlardır. Bu yönüyle SBK içerikli yapılan çalışmalarda kadınların GDO, organ bağışı, küresel ısınma gibi konulara yaklaşımlarında duygusal yönlerinin duyuşsal eğilimlerinde etkili olabileceği tahmin edilebilir. Yapılan bu araştırmalar sonucunda kadın öğretmen adaylarının erkek adaylara göre SBK'ye yönelik daha ayrıntılı bir bakış açısıyla ve (SBK'ye) önem vererek baktığı söylenebilir. Oysa Tekin ve Aslan (2019) yaptıkları araştırmada öğretmen adaylarının cinsiyet değişkeni açısından sosyobilimsel konulara yönelik görüşlerinin istatistiksel olarak farklılaşmadığı sonucuna ulaşmışlardır. Farklı bir çalışmada Zeidler ve Keefer (2003), cinsiyetin sosyobilimsel konulara dair karar vermeyi çok etkilemediği sonucuna ulaşmıştır.

Araştırmadan elde edilen bulgulara göre 3 ve 4. sınıflarda öğrenim gören öğretmen adaylarının sosyobilimsel konuların öğretimine yönelik duyuşsal eğilimlerinde yalnızca "Öz yeterlilik" alt boyutunda 4. sınıftaki adayların lehine anlamlı bir fark olduğu belirlenmiştir. Bunun sebebinin son sınıfta sosyobilimsel konuları içeriğine alan tüm dersleri görmüş olmanın verdiği bir yeterlilik algısı olduğu söylenebilir. Cebesoy ve Dönmez (2013), çalışmasında Fen Bilgisi öğretmen adaylarının sınıf düzeyi değişkenine göre sosyobilimsel konulara ilişkin görüşlerinde herhangi bir farklıllğa rastlamamıştır. Oysa Uysal vd. (2018), tarafından sosyobilimsel bir konu olan genetiği değiştirilmiş uygulamalara yönelik öğretmen adaylarıyla yapılan çalışma sonucunda, öğretmen adaylarının tutumunun sınıf seviyesine göre farklılaştığını belirlenmiştir. Bu çalışmaya göre sınıf seviyesi arttıkça bu konularla ilgili görüşlerin olumlu yönde arttığını söyleyebiliriz. Ayrıca öz yeterlilik alt boyutunda sınıf seviyesinin artması ile anlamlı bir farklılığın ortaya çıkması, bireylerin deneyimleriyle kendine güvenmelerinin doğru orantılı bir şekilde artmasıyla ilişkilendirilebilir.

Araştırmada elde edilen bulgulara göre öğretmen adaylarının sosyobilimsel konuların öğretimine yönelik duyuşsal eğilimlerinde anne eğitim düzeyine göre anlamlı bir farklılık bulunmamıştır. Çalışmayı destekler nitelikte 
Uysal vd. (2018), sosyobilimsel bir konu olan genetiği değiştirilmiş uygulamalara yönelik öğretmen adaylarıyla yapılan çalışmada adayların anne eğitim düzeylerinin bu konulara yönelik görüşleriyle herhangi bir anlamlılık ifade etmediği ortaya konulmuştur. Oysa çalışma sonucundan farklı olarak Çepni (2020), yaptığı tez çalışmasında Sosyal Bilgiler öğretmen adaylarının sosyobilimsel konulara yönelik görüşlerini incelemiş ve nicel araştırmasının sonuçlarında görüşlerin anne eğitim durumu değişkenine göre anlamlı farklılık gösterdiğini belirtmiştir. Çalışmalarda farklı sonuçların elde edilmesinin sebebi katılımcıların annelerinin almış oldukları eğitim, çevre ve yaşam şartları gibi faktörlere göre değişebileceği tahmin edilebilir.

Elde edilen bulgulara göre öğretmen adaylarının sosyobilimsel konuların öğretimine yönelik duyuşsal eğilimlerinde baba eğitim düzeyi değişkenine göre anlamlı bir farklılık bulunmamıştır. Bulgular anne eğitim düzeyi değişkeni ile karşılaştırıldığında tek farkın tutum alt boyutunda olduğu görülmektedir. Alan yazında sosyobilimsel konularla ilgili baba eğitim düzeyi değişkenini araştıran sayılı çalışma bulunmaktadır. Çepni (2020), çalışmasında Sosyal Bilgiler öğretmen adaylarından sosyobilimsel konulara yönelik toplamış olduğu verilerin baba eğitim düzeyi değişkenine göre herhangi bir anlamlılık ifade etmediğini belirtmiştir. Çalışmanın bulguları yapılan çalışmayla da örtüşmektedir. Bu çalışmadan elde edilen bulguyla çelişir nitelikte Çavuş (2013), epistemolojik inanışları gelişmiş ve gelişmemiş 49 adet 8. sınıf öğrencisi belirlemiş ve (bu) öğrencilerin birçok değişkene göre sosyobilimsel konularla ilgili görüşlerini incelemiştir. Araştırma sonucunda öğrencilerden elde edilen bulguların baba eğitim düzeyine göre anlamlı farklılık gösterdiği belirtilmiştir. Çalışmalardaki katılımcı sayılarının değişkenlik göstermesi ve babalarının yaşadığ 1 çevreye, eğitim durumlarına göre ortaya çıkan farklılıkların olduğu söylenebilir.

Araştırmada elde edilen bulgulara göre öğretmen adaylarının sosyobilimsel konuların öğretimine yönelik duyuşsal eğilimlerinde aile yerleşim yeri değişkenine göre anlamlı bir farklılık bulunmamıştır. Demiral ve Türkmenoğlu (2018), çalışmalarında Genetiği Değiştirilmiş Organizmalı (GDO) besinler gibi sosyobilimsel bir konuda Fen Bilgisi öğretmen adaylarının risk algılarını bazı faktörler açısından incelemişlerdir. Araştırma sonucunda adayların ailelerinin yaşadığı yerleşim yerlerinin öğretmen adaylarının risk algıları üzerinde anlamlı düzeyde bir etkisi olmadığı ifade edilmiştir.

Analiz sonuçlarından elde edilen verilere göre fen bilimleri öğretmen adaylarının sosyobilimsel konuların öğretimine yönelik duyuşsal eğilimleri aile gelir düzeylerine göre yalnızca öz yeterlik alt boyutunda anlamlı farklılık göstermektedir. Yolagiden (2017), tez çalışmasında öğretmen adaylarının fen öğrenme becerisi, fen okuryazarlığı ve sosyobilimsel konulara yönelik tutumları arasındaki ilişkiyi incelemiştir. Araştırma sonucuna göre adayların sosyobilimsel konulara ilişkin tutumlarıyla aile gelir düzeyleri arasında anlamlı bir farklılığa rastlanmamıştır.

Araştırma sonuçlarına dayalı olarak şu önerilerde bulunulabilir:

1. $\mathrm{Bu}$ araştırma, Fen Bilimleri öğretmen adaylarının sosyobilimsel konuların öğretimine yönelik duyuşsal eğilimlerini incelemek amacıyla yapılmıştır. Benzer bir konu için örneklem grubu içerisine Biyoloji öğretmenliği, Sınıf öğretmenliği, Sosyal Bilgiler öğretmenliği adayları da katılarak ve değişken sayısı arttırılarak başka bir çalışma yapılabilir.

2. Geliştirilen ölçek ile her eğitim düzeyinde görev yapan Biyoloji, Sınıf, Fen Bilimleri ve Sosyal Bilgiler öğretmenlerinin sosyobilimsel konuların öğretimine yönelik duyuşsal eğilimleri araştırılabilir.

3. Bu çalışmanın amacıyla da benzer nitelikte, sosyobilimsel konuların öğretimi ile ilgili farklı branşlardan öğretmen adayları ile örneklem sayısı azaltılarak daha derinlemesine bilgilerin elde edilebileceği nitel bir araştırma yapılabilir.

\section{Araştırmacıların Katkı Oranı}

$\mathrm{Bu}$ makale, birinci yazarın ikinci yazarın danışmanlığında tamamladığı yüksek lisans tezine dayalı olarak oluşturulmuştur.

\section{Destek ve Teşekkür}

Yazarlar çalışma için herhangi bir finansal destek almamışlardır.

\section{Çıkar Çatış̧ması}

Yazarlar çalışmada herhangi bir çıkar çatışmasının bulunmadığını beyan etmişlerdir. 


\section{Kaynakça / References}

Alaçam-Akşit, A. C. (2011). Sınıf öğretmeni adaylarının sosyobilimsel konularla ve bu konuların öğretimiyle ilgili görüşleri (Yüksek Lisans Tezi). Ege Üniversitesi, İzmir.

Bandura, A. (1986). Social foundations of thought and action: A social cognitive theory. New Jersey: Prentice Hall.

Cebesoy, Ü. B. \& Dönmez Şahin, M. (2013). Fen Bilgisi öğretmen adaylarının sosyobilimsel konulara yönelik tutumlarının çeşitli değişkenler açısından incelenmesi. Marmara Üniversitesi Ĕ̈itim Bilimleri Dergisi, 37, 100-117.

Cronbach, L. J. (1951). Coefficient alpha and the internal structure of tests. Psychometrika, 16(3), 297-334.

Çavuş, R. (2013). Farklı epistemolojik inanışlara sahip 8. Sınıf öğrencilerinin sosyobilimsel konulara bakış açıları (Yüksek Lisans Tezi). Sakarya Üniversitesi, Sakarya.

Çepni, S., Bacanak, A., \& Küçük, M. (2003). Fen eğitiminin amaçlarında değişen değerler: Fen-Teknoloji-Toplum. Değerler Eğitimi Dergisi, 1(4), 7-29.

Çepni, Z. (2020). Sosyal Bilgiler öğretmen adaylarının sosyobilimsel konulara yönelik tutum ve görüşlerinin incelenmesi (Yüksek Lisans Tezi). Recep Tayyip Erdoğan Üniversitesi, Rize.

Dawson, V. M. \& Venville, G. (2009). High school students informal reasoning and argumentation about biotechnology: An indicator of scientific literacy. International Journal of Science Education, 31(11), 1421-1445.

Demiral, Ü., \& Türkmenoğlu, H. (2018). Fen Bilgisi öğretmen adaylarının sosyobilimsel bir konuda karar verme stratejilerinin alan bilgileriyle ilişkisi. Uludă̆ Üniversitesi Eğitim Fakültesi Dergisi, 31(1), 309-340.

Field, A. (2009). Discopering statistics using SPSS. Londra: Third Edition.

Genç, M. \& Genç, T. (2017). Türkiye'de sosyobilimsel konular üzerine yapılmış araştırmaların içerik analizi. Kafkas Üniversitesi Kafkas Eğitim Araştırmaları Dergisi, 4(2), 19-26.

İpek, C., \& Bayraktar, Ş. (2004). Aday öğretmenlerin fen bilimleri ve sosyal bilimlere bakışları. Yüzüncü Yll Üniversitesi Ĕ̆itim Fakültesi Dergisi, 1, 35-50.

Kara, Y. (2012). Pre-service biology teachers' perceptions on the instruction of socio-scientific issues in the curriculum. European Journal of Teacher Education, 35(1), 111-129.

Karasar, N. (1994). Bilimsel araştırma yöntemi. Ankara: 3A Araştırma Eğitim Danışmanlık Ltd.

Kolsto, S.D. (2006). Patterns in students' argumentation confronted with a risk-focused socio-scientific issue. International Journal of Science Education, 28(14), 1689-1716.

Lee, H., Witz, G. K. (2008). Science teachers' inspiration for teaching socioscientific issues: Disconnection with reform efforts. International Journal of Science Education, 1-30.

Lumley, T., Diehr, P., Emerson, S. \& Chen, L. (2002) The importance of the normality assumption in large public health data sets. Annual Review of Public Health, 23, 151-169.

MEB (2006). İlkögrretim kurumları (ilkokullar ve ortaokullar) fen bilimleri dersi öğretim programı. Ankara: MEB Yayınları.

MEB (2018). İlköğretim kurumları (ilkokullar ve ortaokullar) fen bilimleri dersi öğretim programı. Ankara: MEB Yayınları.

Owens, D.C., Sadler, T.D. ve Friedrichsen, P. (2019). Teaching practices for enactment of socio-scientific issues instruction: An instrumental case study of an experienced biology teacher. Research in Science Education, 48, 1-24.

Özhan, M. M. (2018). Sosyobilimsel konuların öğretimine yönelik bir profesyonel gelişme çalışmasının fen bilimleri ögretmenlerinin sosyobilimsel konuların doğası ile ilgili inançlarına olan etkileri (Yüksek Lisans Tezi). Uludağ Üniversitesi, Bursa. 
Qin, W., \& Brown, J. L. (2007). Public reactions to information about genetically engineered foods: Effects of information formats and male/female differences. Public Understanding of Science, 16(4), 471-488.

Reis, P., ve Galvão, C. (2009). Teaching controversial socio-scientific issues in biology and geology classes: A case study. Electronic Journal of Science Education, 13(1).

Sadler, T. D. (2004). Informal reasoning regarding SSI: A critical reviev of research. Journal of Research in Science Teaching, $41(5), 513-536$.

Schermelleh-Engel, K., Moosbrugger, H., \& Müller, H. (2003). Evaluating the fit of sturctural equation models: Tests of significance and descriptive goodness-of-fit measures. Methods of Psychological Research Online, 8, 23-74.

Shulman, L. S. (1987). Knowledge and teaching: Foundations of the new reform. Harvard Educational Review, 57(1). 1-22.

Sıbıç, O. (2017). Fen Bilgisi öğretmen adaylarının sosyobilimsel konulara ve sosyobilimsel konu temelli öğretime yönelik görüşleri (Yüksek Lisans Tezi). Yıldız Teknik Üniversitesi, İstanbul.

Sönmez, A., \& Kılınç, A. (2012). Preservice science teachers' self-efficacy beliefs about teaching GM foods: The potential effects of some psychometric factors. Necatibey Journal of Science and Mathematics Education, 6(2), 49-76.

Sürmeli, H., \& Şahin, F. (2010). Üniversite öğrencilerinin genetik mühendisliği ile ilgili biyoetik görüşleri: Genetik testler ve genetik tan1. Journal of Turkish Science Education, 7(2), 119-132.

Tekin, N., \& Aslan, O. (2019). Öğretmen adaylarının sosyobilimsel konulara yönelik tutumlarının çeşitli değişkenler bakımından incelenmesi. Firat Üniversitesi Sosyal Bilimler Dergisi, 29(1), 133-141.

Topçu, M. S. (2010). Development of attitudes towards socioscientific issues scale for undergraduate students. Evaluation and Research in Education, 23(1), 51-67.

Topçu, M. S. (2017). Sosyobilimsel konular ve ögretimi. Ankara: Pegem Akademi.

Uysal, E., Cebesoy, Ü. B., \& Karışan, D. (2018). Fen bilgisi öğretmen adaylarının genetik uygulamalarına yönelik tutumlarının çeşitli değişkenler açısından incelenmesi. Batı Anadolu Ĕgitim Bilimleri Dergisi, 9(1), 1-14.

Yıldırım, A., \& Şimşek, H. (2013). Sosyal bilimlerde nitel araştırma yöntemleri (9. baskı). Ankara: Seçkin Yayıncılık.

Yılmaz, V. \& Çelik, H.E. (2013). Lisrel ile yapısal eşitlik modellemesi. Ankara: Anı Yayıncılık.

Yiğittir, S., \& Çalışkan, H. (2013). Seviye belirleme sınavında (SBS) Sosyal Bilgiler alanında sorulan soruların kapsam geçerliği açısından incelenmesi. Milli Eğitim Dergisi, 42(197), 145-157.

Yolagiden, C. (2017). Öğretmen adaylarının fen öğrenme becerisi, fen okuryazarlı̆̆l ve sosyobilimsel konulara yönelik tutumları arasındaki ilişkinin araştırılması (Yüksek Lisans Tezi). Kahramanmaraş Sütçü İmam Üniversitesi, Kahramanmaraş.

Zeidler, D. L., \& Keefer, M. (2003). The role of moral reasoning and the status of socioscientific issues in science education. In the Role of Moral Reasoning on Socioscientific Issues and Discourse in Science Education, 7-38. 
Ek-1 Sosyobilimsel Konuların Öğretimine Yönelik Duyuşsal Eğilim Ölçeği.
Cinsiyet :
( ) Kadın
( ) Erkek

Okul Adı :

Sinif
Ailenizin Yerleşim Yeri : ( ) Büyükşehir
( ) İl merkezi
( ) İlçe
( ) Köy
Anne Eğitim Düzeyi ( ) İlkokul ( ) Ortaokul ( ) Lise ( ) Lisans ( ) Lisansüstü ( ) Diğer
Baba Eğitim Düzeyi ( ) İlkokul ( ) Ortaokul ( ) Lise ( ) Lisans ( ) Lisansüstü ( ) Diğer

Ailenin Gelir Durumu (€) : ( ) 0-750 ( ) 750-1500 ( ) 1500-2250 ( ) 2250-3000 ( ) 3000 ve üzeri

\begin{tabular}{|c|c|c|c|c|c|c|c|}
\hline Faktör & No & & 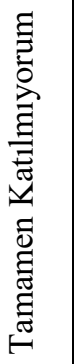 & 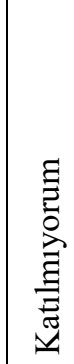 & 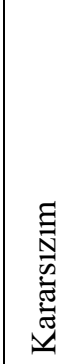 & 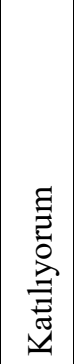 & 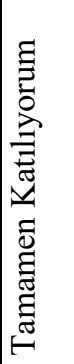 \\
\hline Öz yeterlilik & 1 & Sosyobilimsel konular hakkında yeterli bilgiye sahibim. & (1) & (2) & (3) & (4) & (5) \\
\hline Öz yeterlilik & 2 & $\begin{array}{l}\text { Sosyobilimsel konular hakkında sahip olduğum bilgileri } \\
\text { öğrencilere aktarabileceğimi düşünüyorum. }\end{array}$ & (1) & 2 & (3) & (4) & (5) \\
\hline Öz yeterlilik & 3 & $\begin{array}{l}\text { Sosyobilimsel konuların öğretiminde farklı yöntem ve } \\
\text { tekniklere yer vereceğimi düşünüyorum. }\end{array}$ & (1) & (2) & (3) & (4) & (5) \\
\hline $\begin{array}{l}\text { Pedagojik Alan } \\
\text { Yeterliliği }\end{array}$ & 4 & $\begin{array}{l}\text { Sosyobilimsel konuların öğretimine başlamadan önce konu } \\
\text { hakkındaki yeni geliş̧eleri araştırııı. }\end{array}$ & (1) & (2) & (3) & (4) & (5) \\
\hline $\begin{array}{l}\text { Pedagojik Alan } \\
\text { Yeterliliği }\end{array}$ & 5 & $\begin{array}{l}\text { Sosyobilimsel konuların öğretiminde konu ile ilgili her } \\
\text { görüš̈u göz önünde bulundurarak öğrencilere aktarmay1 } \\
\text { düşünüyorum. }\end{array}$ & (1) & (2) & (3) & (4) & (5) \\
\hline $\begin{array}{l}\text { Pedagojik Alan } \\
\text { Yeterliliği }\end{array}$ & 6 & $\begin{array}{l}\text { Sosyobilimsel konuların öğretiminde öğrencilerin ön bilgileri } \\
\text { ile aktarılacak konu hakkında ilişki kurmalarını } \\
\text { sağlayabilirim. }\end{array}$ & (1) & (2) & (3) & (4) & (5) \\
\hline $\begin{array}{l}\text { Pedagojik Alan } \\
\text { Yeterliliği }\end{array}$ & 7 & $\begin{array}{l}\text { Sosyobilimsel konuları öğretiminde medya } \\
\text { araçlarını(gazete, internet vb.) kullanmayı tercih ederim. }\end{array}$ & (1) & (2) & (3) & (4) & (5) \\
\hline $\begin{array}{c}\text { Pedagojik Alan } \\
\text { Yeterliliği }\end{array}$ & 8 & $\begin{array}{l}\text { Öğrencilere sosyobilimsel konuların etik ve sosyal boyutunu } \\
\text { tartışmaları için gerekli ortamı sağlamayı düşünüyorum. }\end{array}$ & (1) & (2) & (3) & (4) & (5) \\
\hline $\begin{array}{l}\text { Pedagojik Alan } \\
\text { Yeterliliği }\end{array}$ & 9 & $\begin{array}{l}\text { Öğrencilerin sosyobilimsel konuların etik boyutlarıyla ilgili } \\
\text { bilgi edinmelerini sağlayacağımı düşünüyorum. }\end{array}$ & (1) & (2) & (3) & (4) & (5) \\
\hline
\end{tabular}




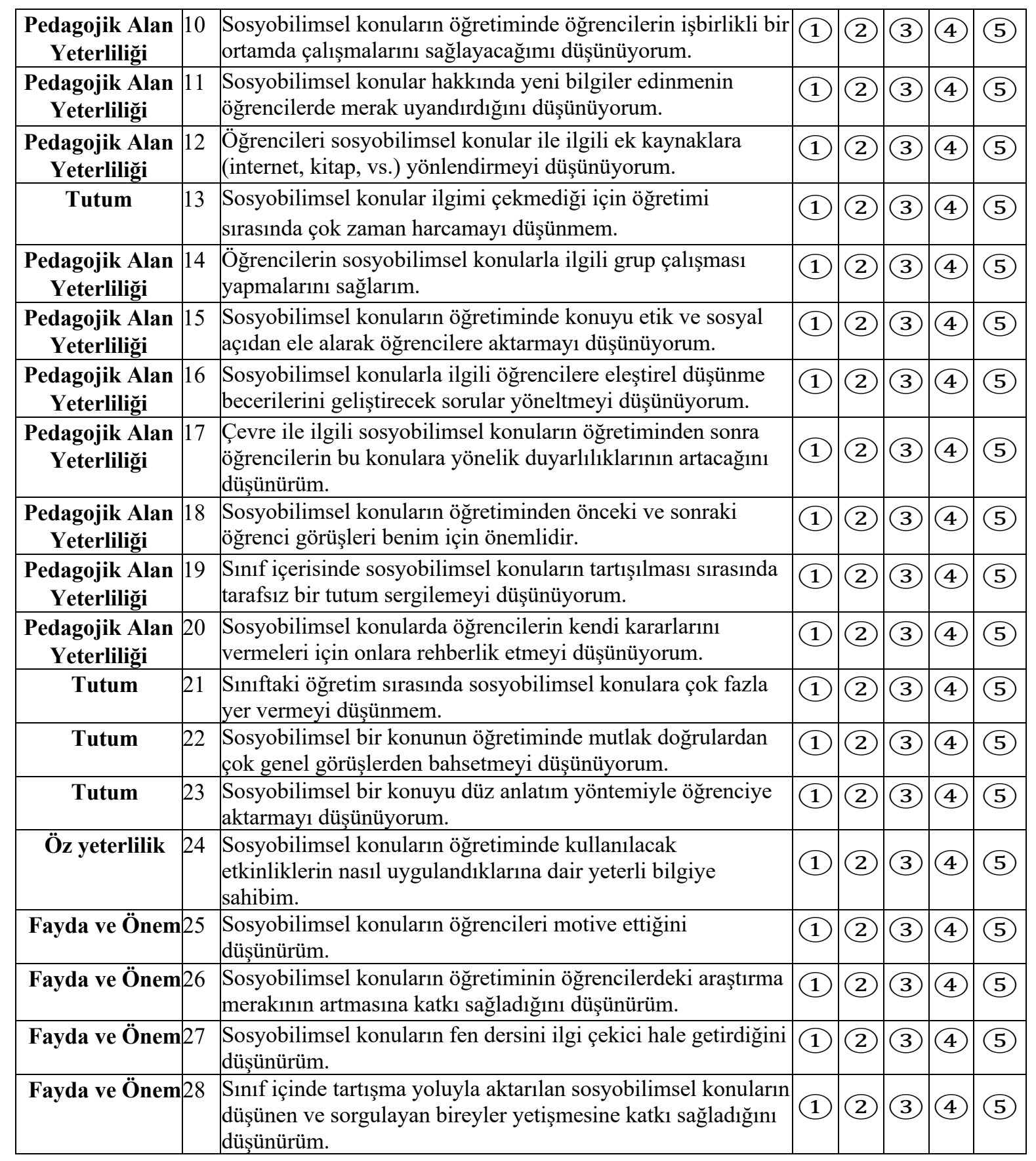

